\title{
The Northeast Greenland Shelf as a Potential Habitat for the Northeast Arctic Cod
}

\author{
Kjersti O. Strand ${ }^{1,2,3 *}$, Svein Sundby ${ }^{1}$, Jon Albretsen ${ }^{1}$ and Frode B. Vikebø ${ }^{1,2}$ \\ ${ }^{1}$ Department of Oceanography and Climate, Institute of Marine Research, Bergen, Norway, ${ }^{2}$ Bjerknes Center for Climate \\ Research, Bergen, Norway, ${ }^{3}$ Geophysical Institute, University of Bergen, Bergen, Norway
}

OPEN ACCESS

Edited by:

Brian R. MacKenzie,

Technical University of Denmark, Denmark

Reviewed by:

Yizhen $\mathrm{Li}$,

Woods Hole Oceanographic Institution, United States

Clive Fox

Scottish Association For Marine

Science, United Kingdom

*Correspondence:

Kjersti O. Strand

kjersti.opstad.strand@imr.no

Specialty section:

This article was submitted to Global Change and the Future Ocean,

a section of the journal

Frontiers in Marine Science

Received: 27 January 2017 Accepted: 04 September 2017 Published: 26 September 2017

Citation:

Strand KO, Sundby S, Albretsen J and Vikebø FB (2017) The Northeast Greenland Shelf as a Potential Habitat for the Northeast Arctic Cod

Front. Mar. Sci. 4:304.

doi: 10.3389/fmars.2017.00304
Observations (1978-1991) of distributions of pelagic juvenile Northeast Arctic cod (Gadus morhua L.) show that up to $1 / 3$ of the year class are dispersed off the continental shelf and into the deep Norwegian Sea while on the way from the spring-spawning areas along the Norwegian coast to the autumn-settlement areas in the Barents Sea. The fate of this variable fraction of pelagic juveniles off-shelf has been an open question ever since Johan Hjort's (1914) seminal work. We have examined both the mechanisms causing offspring off-shelf transport, and their subsequent destiny using an individual-based biophysical model applied to quantify growth and dispersal. Our results show, consistently with the observations, that total off-shelf transport is highly variable between years and may be up to $27.4 \%$. Offspring from spawning grounds around Lofoten have a higher chance of being displaced off the shelf. The off-shelf transport is dominated by episodic events where frequencies and dates vary between years. Northeasterly wind conditions over a 3-7-day period prior to the off-shelf events are a good proxy for dispersal of offspring off the shelf. Offspring transported into the open ocean are on average carried along three following routes: back onto the adjacent eastern shelves and into the Barents Sea (36.9\%), recirculating within the Lofoten Basin (60.7\%), or drifting northwest to the northeast Greenland shelf $(2.4 \%)$. For the latter fraction the transport may exceed $12 \%$ depending on year. Recent investigations have discovered distributions of young cod on the northeast Greenland shelf indicating that conditions may support survival for Northeast Arctic cod offspring.

Keywords: connectivity, pelagic juvenile, cross-shelf, spawning ground, nursery ground, forecast, northeast arctic cod, recruitment

\section{INTRODUCTION}

The Northeast Arctic (NEA) cod, the historically largest stock of Atlantic cod (Gadus morhua L.) (Yaragina et al., 2011), has its feeding area in the Barents Sea and undertakes spawning migration southwards along the Norwegian coast during winter, partly far outside its feeding habitat (Bergstad et al., 1987). After spawning in March and April (Ellertsen et al., 1989) from Møre $\left(62^{\circ} \mathrm{N}\right)$ to the Finnmark coast $\left(71^{\circ} \mathrm{N}\right)$ (Sundby and Nakken, 2008) the offspring returns to the Barents Sea by pelagic drift in the Norwegian Coastal Current (NCC) on the shelf and in part in the more offshore Norwegian Atlantic Slope Current (NASC) that runs parallel to the NCC (Vikebø et al., 2005). En route toward the Barents Sea, they drift in the upper mixed layer where shifting winds due to passing weather systems significantly affects strength and direction of the flow, making them vulnerable to the variable meteorological conditions (Vikebø et al., 2007). By October, when the 
pelagic juveniles have reached a typical length of more than $8 \mathrm{~cm}$, they gradually migrate out of the pelagic layer (Yaragina et al., 2011) and become associated with depths closer to the bottom, which in the Barents Sea ranges from 150 to more than $350 \mathrm{~m}$ depth. From that stage, they are distributed over their natural habitat at the shelf region in the Barents Sea (Figure 1).

Similarly, cod stocks across the North Atlantic have their habitats confined to the continental shelves fringing the North Atlantic proper (Sundby, 2000). The pelagic eggs, larvae and free-drifting early juveniles that happen to become advected by variable currents out over the deep ocean have generally been considered lost for recruitment to the stock (e.g., Werner et al., 1993, 1997). This idea, i.e., that drift of pelagic offspring to unfavorable regions might cause recruitment loss, was already suggested by Hjort (1914), and later defined by Sinclair et al. (1985) as Hjort's second recruitment hypothesis.

Based on the post-larval (hereafter denoted pelagic juvenile) surveys conducted by the Institute of Marine Research (IMR) during the period 1977-1991 (sampled in June/July at an average age of $\sim 70$ days) it became evident that a variable portion, and in some years, a quite considerable one, of the new year class of cod was, indeed, found off the shelf in the Norwegian Sea (Bjørke and Sundby, 1987; Sundby et al., 1989). In the year 1988, which had the largest number of observed larvae offshore among these years, 35\% of the year class of cod as pelagic juveniles was found in the deep-sea region off the shelf to the west of the NASC (Suthers and Sundby, 1993). Moreover, analysis of length, condition factor, and age (based on counts of daily otolith rings) discovered that this "stray" portion of the 1988 yearclass consisted of larger individuals in better condition than the portion of the year class than was "on the right track" toward the Barents Sea. Suthers and Sundby (1993) ascribed this to higher accumulated ambient temperature, and hypothesized that higher zooplankton food abundances in the Norwegian Sea could be a second factor causing the increased growth as the Norwegian Sea proper is the core region for abundance of the main prey species Calanus finmarchicus (Sundby, 2000).

Similar to the off-shelf observations from pelagic juvenile surveys, the subsequent 0 -group stage, observed during August and September by IMR-surveys, have years when the 0-group is partly found to the west of the shelf edge outside the natural habitat in the Barents Sea, apparently also in high concentrations (see maps of distributions in Eriksen and Prozorkevich, 2011). However, since the 0 -group survey only covers a small area outside the western fringe of the Barents Sea it is not possible to quantify how large portion of the year class that exists outside the natural habitat at this stage.

Although such considerable portions of pelagic juvenile cod have repeatedly been observed off the prevailing current paths to the Barents Sea habitat, the destinies of these individuals have never been explored in further detail, most probably because the prevailing view has been dominated by Hjort's second recruitment hypothesis which posits that they might simply be lost for recruitment. However, for the NEA cod there are alternative scenarios. Johan Hjort (1914) himself pointed to one such alternative following his recruitment hypotheses: "During the first cruise of the "Michael Sars" in the Norwegian Sea,
I encountered great numbers of young cod fry drifting in the water above the great depression in this region. It is possible that many individuals perish during such drift movements; nothing is, however, definitely known as to this. It would be especially desirable to ascertain the extent of such movement, and how far the young fry is able to return, of their own volition, to such localities as offer favorable conditions for their further growth." In other words, as a second alternative, if the pelagic juveniles in this western region attain a systematic and sustained swimming behavior toward the east they might return to the water masses that flow into the Barents Sea (e.g., Staaterman and Paris, 2013).

A third alternative is that the pelagic juveniles are successfully transported with the currents either back onto the eastern shelves or onto the large northeastern Greenland shelf where they might settle and grow up as a geographically separated component of NEA cod. Independent of this reasoning, a traditional folklore opinion in some Norwegian coastal fishing communities has been that Greenland cod occasionally spawn in Norwegian waters. This opinion might possibly be based on fishermen visiting Greenland waters observing specific morphometric (phenotypic) characteristics of the cod growing up in Greenland waters that they recognize in Norwegian spawning sites. In a possible support, of considering the northeastern Greenland shelf as being a distant part of NEA cod habitat, are recent findings of adult cod in the area (Christiansen et al., 2016), see Figure 1.

In this current study, we address the impacts of advection and dispersion of the offspring from the spawning area to the areas of subsequent settlement about half a year later. More specifically, we focus on the third alternative and address four main research questions related to the above outline by applying a state-of the-art biophysical model coupled with in-situ data. (1) What fraction of the NEA cod spawned along the Norwegian coast is advected westward off the continental shelf, and how large is the variability in this off-shelf drift within and between years? (2) Which spawning grounds have the highest probability for off-shelf drift of cod offspring? (3) What are the mechanisms and forcing causing the off-shelf transport? (4) Where do the observed off-shelf pelagic juveniles finally end up, and what is the relative number of individuals following the alternative transport routes?

\section{MATERIALS AND METHODS}

Firstly, we modeled transport for the years 1978-2015 with particles initiated as eggs at 10 well-known spawning sites for NEA cod along the Norwegian coast (Figure 1; Sundby and Nakken, 2008) investigating questions 1-3. Particles are being transported by an individual-based particle tracking model (IBM) utilizing daily 3D oceanic currents from an ocean model archive resulting from simulations with the Regional Ocean Modeling System (ROMS) model ${ }^{1}$ (Shchepetkin and McWilliams, 2005; Lien et al., 2014, 2016). Since transportation off the shelf and shelf circulation above complex topography might be significantly influenced by small-scale dynamics, this part of the study was done with two different ocean model

${ }^{1}$ www.myroms.org 


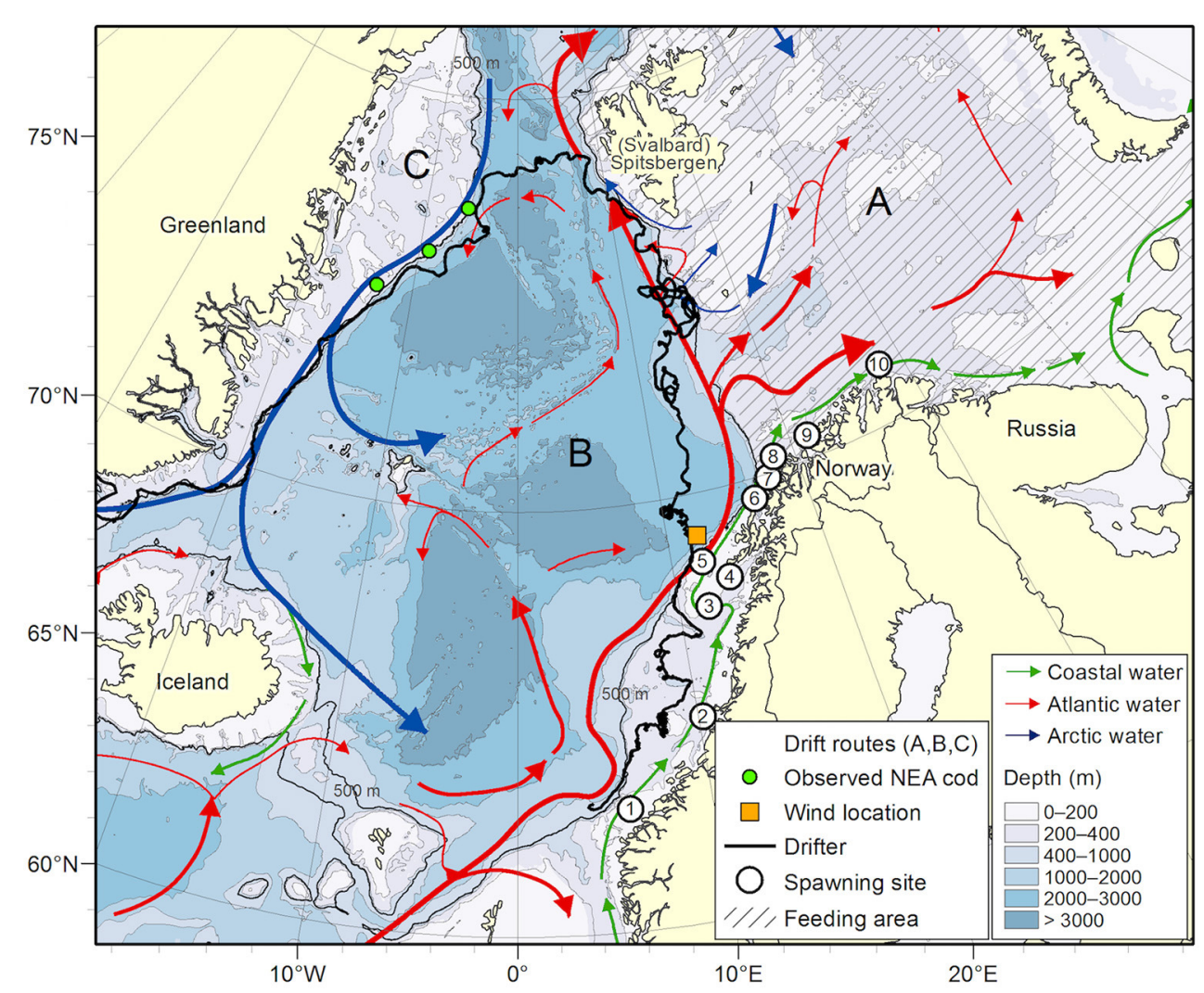

FIGURE 1 | Circles with numbers indicate the 10 spawning grounds where particles representing eggs are initiated. The orange square indicates the location from where winds are correlated with off-shelf transport of particles and ocean currents perpendicular to the shelf edge. The thin black line shows the $500 \mathrm{~m}$ isobath (here; the shelf edge). The thick black trajectory shows the 2009 drifter with arrival at the Greenland shelf as commented in section Connectivity Studies on Atlantic Cod. Locations of observed cod on Greenland are marked with green dots (taken from Christiansen et al., 2016). Currents are marked as NCC (green arrow), AW/NASC (red arrow), and Arctic water (blue arrow). Dashed area is the average long-term spatial extent of the NEA cod's feeding area, and modeled distribution areas (drift routes) are indicated with A, B, and C, see section Transport Pattern of Pelagic Juveniles Off the Shelf Edge for explanation.

archives; both the daily mean 3D circulation archive, and an hourly mean $3 \mathrm{D}$ archive with an even finer grid resolution.

The weighted (see section Individual-Based Model) model distributions from known spawning grounds were evaluated against observed pelagic juveniles (see section Pelagic Juvenile Observations). For each observation location, the weighted model distribution of pelagic juveniles was summarized across the nearest four by four grid cells, still less than the distance between observations, and compared to the observations. A match is accomplished when both or neither observed and modeled pelagic juveniles are present. However, results must be interpreted with care as the biophysical model do not include natural mortality. Furthermore, the transportation of NEA cod juveniles off the shelf was correlated with NORA10 wind (see section Ocean Model and Atmospheric Forcing). In addition, we correlated the wind forcing against the modeled current component perpendicular to the shelf edge at different depth intervals in order to evaluate the potential for transportation off the shelf.

Secondly, investigating question 4, we initialized particles according to the annual observed distributions of pelagic juvenile
NEA cod off the continental shelf and followed their free pelagic drift toward nursery grounds for years with observations (19781991). The aim of this exercise was to investigate alternative drifts routes and new potential nursery habitats.

\section{Ocean Model}

The main ROMS model applications used here is the 4 by 4 $\mathrm{km}$ resolved horizontal grid covering the Nordic Seas and the Barents Sea for the period 1958-2015 with 32 vertical sigma layers forced by the Simple Ocean Data Assimilation data set (SODA; Carton and Giese, 2008) on the lateral boundaries and regional downscaled European Centre for Medium-Range Weather Forecasts (ECMWF) re-analysis (ERA-40; Uppala et al., 2005) combined with previous prognostic runs to a grid with 10 by $10 \mathrm{~km}$ resolution (hereafter denoted NORA10) at the sea surface (hereafter denoted SVIM, see Lien et al., 2014). In the vertical, the spatio-temporal eddy diffusivity terms from the local turbulence closure scheme were used (a Generic Length Scale mixing scheme with $\mathrm{k}-\omega$ setup) in ROMS (Umlauf and Burchard, 2003; Umlauf et al., 2003). See Warner et al. (2005) for a thorough evaluation comparing different mixing schemes. 
The ocean model archive, SVIM, has proven to reproduce many observed oceanographic features in the area (Lien et al., 2014, 2016) motivating its use for investigating intra- and inter-annual variations in drift trajectories from observed spawning grounds. In addition, we have used an 800 by $800 \mathrm{~m}$ horizontal resolution application with 35 sigma layers covering the entire Norwegian coast from the Skagerrak and the northern North Sea to the Barents Sea extending from the fjords out into the deep basin off the shelf edge (Albretsen et al., 2011, hereafter denoted the NorKyst800). The NorKyst800 hindcast covers the period 20052015 and has lateral boundary forcing from SVIM.

\section{Atmospheric Forcing}

Atmospheric forcing for the two ROMS applications were taken from NORA10 (Reistad et al., 2011), providing 6-hourly winds, temperature, pressure, humidity, cloud cover, and accumulated precipitation, while radiative forcing is computed internally in ROMS.

\section{Individual-Based Model}

Egg, larvae and pelagic juvenile drift are reproduced by particles advected by simulated currents in the IBM model "Lagrangian Diffusion Model" (Ådlandsvik and Sundby, 1994). The "Lagrangian Diffusion Model" is a simple particle-tracking model with a 4th order Runge-Kutta advection scheme and a sub-module handling individual physiological and behavioral responses to environmental forcing. It implies that the variable physical environment is included in the biological sub-module, but the variability in prey and predator field is uncertain and not known to a sufficient degree in relevant spatial and temporal scales to estimate the mortality and, hence, not included. Due to the horizontal resolution of the SVIM-archive (4 km), mesoscale vorticity is underestimated (Isachsen et al., 2012). Therefore, a horizontal eddy diffusive term (with turbulent diffusion coefficient $K=1 \mathrm{~m}^{2} \mathrm{~s}^{-1}$, chosen after testing different values) is included to compensate for the lack of resolving mesoscale processes. The same was included when using the NorKyst800 as forcing for particle dispersal. Vertical distribution of eggs is based on individual egg size and density (Sundby, 1983), modeled ocean densities and levels of turbulence in the water column at the individual time-varying location of each egg (based on Thygesen and Ådlandsvik, 2007; utilized in e.g., Opdal et al., 2011; Röhrs et al., 2014). The larval and juvenile growth function is taken from Folkvord (2005) and based on laboratory experiments for a range of temperatures under constant satiated feeding of the offspring. Vertical migration is included as a diel migration between upper and lower limits depending on light conditions and swimming capability $(5-30 \mathrm{~m}$ during night and $10-40 \mathrm{~m}$ during day, with night defined as light levels below 1.0 micromole photons per $\mathrm{m}^{2} \mathrm{~s}^{-1}$, see Opdal et al., 2011). A well-known challenge in Lagrangian particle-tracking models is the handling of particles advected near land. We tested different land-handling schemes to avoid abnormal stranding along the irregular coast. We decided to implement a solution where particles were only moved in the direction of the offshore velocity component if they were to be moved onto land in the next time step. The IBM was run with two different setups, one with particles initiated at well-known spawning grounds along the Norwegian coast for the years 1978-2015, and another with particles initiated according to observed offshore pelagic juveniles for the years 1978-1991. For both setups, the particles are initiated at $5 \mathrm{~m}$ depth.

When initiating eggs at the spawning grounds, we released 200 particles at each site every day during the known spawning period from March 1st until April 30th and followed each particle for 200 days to analyze dispersal. The model results were adjusted by weighting the importance of each particle to reflect a Gaussian spawning intensity in time with peak spawning at April 1st and by considering the yearly geographically distribution across spawning grounds using observations from egg surveys (Ellertsen et al., 1987; Sundby and Bratland, 1987; Sjølingstad, 2007; Sundby and Nakken, 2008) and observations on abundance of spawning NEA cod (see the supplementary section for complete references 1978-2004, and data from IMR's spawning migration cruises 2005-2015 held at IMR fish database). The particles are initiated as eggs and continue as hatched larvae after about 2-3 weeks depending on ambient temperatures.

To initiate the model with the observed distributions of pelagic juveniles we released 500 particles at each offshore station with observed NEA cod at the mid-date of the year-specific survey (Table 1) and followed each particle for 120 days until November when NEA cod reach the stage of settling to the bottom in the Barents Sea, i.e., their transition from a pelagic to a demersal habitat (Ottersen et al., 2014).

\section{Pelagic Juvenile Observations}

During the years 1977-1991 scientific surveys ${ }^{2}$ covered yearspecific observational grids towing trawls of various sizes at a speed of 2-3 knots (Bjørke and Sundby, 1984, 1987; Suthers and Sundby, 1993, 1996). The number of stations, geographic coverage and duration of the surveys varied between years (Table 1). The median spatial resolution between each station was $26 \mathrm{~km}$. The surveys lasted from 16 to 49 days within the period June 18th to August 5th, with mid-date for offshore stations between June 28th and July 26th. The sampling gear used started with a pelagic meshed midwater trawl with an opening of $4 \times 10 \mathrm{~m}$ in 1977, $18 \times 18 \mathrm{~m}$ from 1978 until 1984, and finally a $29 \times 29 \mathrm{~m}$ trawl opening from 1985 and onwards. Here, we have omitted the first year, 1977, since this is considered a test survey where the trawl used was too small. All trawls had diminishing mesh sizes toward the cod end and a $4 \mathrm{~m}$ long net with a mesh size of $4 \mathrm{~mm}$ (stretched) at the inner part of the cod end. During 1978 through 1984 two hauls were made at each station; one haul with the headline at 40 and $20 \mathrm{~m}$ depth, and a towing time of $15 \mathrm{~min}$ in each depth interval, and the second haul at the surface with five big floats on the headline and a towing time of $30 \mathrm{~min}$. From 1985 through 1991 the depths were the same as the previous years, but the towing time at each depth interval was halved (Bjørke and Sundby, 1987).

\section{General Circulation Features}

The circulation features of the northeastern North Atlantic are governed by the two-branched northward flow of warm and salty Atlantic Water (AW) across the Faeroe-Shetland Channel (Hansen and Østerhus, 2007; Eldevik et al., 2009) along the

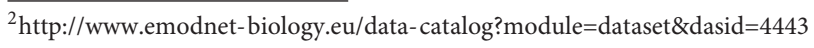


TABLE 1 | NEA cod pelagic juvenile survey details between 1978 and 1991 and corresponding modeling.

\begin{tabular}{|c|c|c|c|c|c|c|c|}
\hline \multicolumn{3}{|c|}{ Observation information } & \multicolumn{5}{|c|}{ Simulation information } \\
\hline Year & $\begin{array}{l}\text { Number of stations in } \\
\text { total/offshore with/offshore } \\
\text { without presence of juveniles }\end{array}$ & $\begin{array}{l}\text { Observed mean length in } \\
\text { total/off-shelf [mm] }\end{array}$ & Start date [dd.mm] & Particles released & Area A [\%] & Area B [\%] & Area C [\%] \\
\hline 1978 & $120 / 22 / 34$ & $28.7 / 28.8$ & 09.07 & 11,000 & 24.7 & 75.3 & 0.0 \\
\hline 1979 & $160 / 15 / 45$ & 23.0/20.9 & 29.06 & 7,500 & 52.0 & 48.0 & 0.0 \\
\hline 1980 & $127 / 1 / 35$ & $20.6 / 22.0$ & 28.06 & 500 & 99.0 & 1.0 & 0.0 \\
\hline 1981 & $193 / 31 / 35$ & $24.5 / 27.5$ & 11.07 & 15,500 & 24.0 & 75.2 & 1.9 \\
\hline 1982 & $155 / 8 / 7$ & $27.2 / 33.3$ & 21.07 & 4,000 & 35.8 & 63.6 & 0.6 \\
\hline 1983 & $100 / 5 / 5$ & $32.2 / 44.9$ & 11.07 & 2,500 & 32.4 & 60.3 & 7.3 \\
\hline 1984 & $145 / 29 / 3$ & $34.4 / 40.0$ & 14.07 & 14,500 & 41.4 & 56.6 & 1.9 \\
\hline 1985 & $129 / 30 / 10$ & $24.3 / 26.8$ & 08.07 & 15,000 & 30.2 & 66.5 & 3.3 \\
\hline 1986 & $197 / 16 / 30$ & $27.0 / 29.3$ & 13.07 & 8,000 & 21.6 & 66.3 & 12.1 \\
\hline 1987 & $217 / 48 / 23$ & $27.8 / 30.0$ & 16.07 & 24,000 & 30.1 & 69.0 & 0.8 \\
\hline 1988 & $242 / 41 / 57$ & $34.8 / 38.5$ & 17.07 & 20,500 & 22.1 & 77.8 & 0.1 \\
\hline 1989 & $242 / 21 / 71$ & $34.1 / 34.7$ & 14.07 & 10,500 & 37.6 & 59.7 & 3.0 \\
\hline 1990 & $111 / 35 / 8$ & $47.3 / 57.7$ & 26.07 & 17,500 & 35.8 & 64.2 & 0.0 \\
\hline 1991 & 163/26/32 & $36.0 / 41.1$ & 12.07 & 13,000 & 30.8 & 66.9 & 2.3 \\
\hline
\end{tabular}

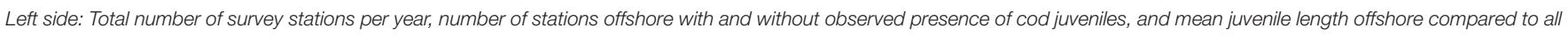

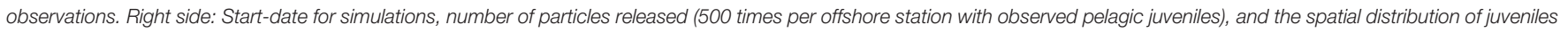
per November 1 st in the three areas $(A-C)$, see explanation in text.

eastern continental slope, the NASC, and a second branch farther off the shelf. Eddy shedding brings AW off the upper shelf slope and into the Lofoten Basin (Rossby et al., 2009; Søiland et al., 2016) where it either recirculates or flows along the Mohn Ridge toward the Jan Mayen area (Isachsen and Nøst, 2012). Farther north the AW bifurcates at the entrance to the Barents Sea with one branch flowing to the northwest of Svalbard and the other entering the Barents Sea. Northwest of Svalbard AW either carries on northeast and east along the shelf north of Svalbard or eddy shedding brings it out into the Fram Strait and southwest along the Greenland Shelf (Hattermann et al., 2016). Figure 1 shows the geographical extent of our study area including the main circulation features.

\section{Predominant Wind Directions and Shelf Edge Orientation}

The focus area of the present study is between 67.0 and $70.0^{\circ} \mathrm{N}$, where the continental shelf is largely oriented to the northeast $\left(42^{\circ}\right.$ from east). Therefore, wind sectors coming from the northerly-easterly/southerly-westerly (NE/SW), within the directional sector of $\pm 45^{\circ}$ of the shelf edge orientation, gives opposite wind sectors against/with the predominating currents. For NE wind, it has the potential to create instability and/or Ekman transport off the shelf edge. We have defined off-shelf areas to include waters deeper than the 500-meter isobath (here named the "shelf edge"). To investigate this further, winds are extracted from NORA10 at a point location at the shelf edge outside Lofoten $\left(69^{\circ} \mathrm{N}, 12^{\circ} \mathrm{E}\right.$, see Figure 1). Directions of wind with strength $<5 \mathrm{~m} / \mathrm{s}$ are not considered anticipating that such wind is insufficient to cause significant perturbations to the predominant along-shelf currents. The main period chosen is
March through July since by then about $70 \%$ of the cod offspring have passed the area of interest (by then) according to the model mean.

\section{RESULTS}

\section{Origin of the Pelagic Juveniles Off the Shelf Edge}

Figure 2A shows the fractions of particles transported off the shelf by mid-September (based on SVIM) from each of the 10 spawning areas for the years 1978-2015. The mean offshelf transport for these years is $11.5 \%$ with a minimum in 2002, and a maximum in 2008. Figure $\mathbf{2 B}$ is similar to Figure 2A, but here the particles are weighted according to observed spawning intensity in time and space (inter- and intraannual, see section Individual-based Model). The mean offshelf transport of NEA cod offspring then increases to $14.7 \%$. The inter-annual variability also increases, reflecting the high weights added to the offspring originating from the Lofoten region (spawning sites 3-5 in Figure 1). In summary, Figure 2A illustrates the potential off-shelf transport from each spawning area, while Figure 2B shows the off-shelf transport based on the actual year-specific weighted spawning intensity from each spawning area. Increasing horizontal resolution in the ocean model (from SVIM to NorKyst800) for the years 2005-2015 resulted in a decreased mean off-shelf transport from 11.5 to $5.6 \%$. However, the variations between the years have similar features between NorKyst800 and SVIM, with highest off-shelf transport in 2008 (2012) without (with) adding weights to the spawning grounds. According to Suthers and Sundby (1993), the fraction of pelagic juveniles found off shelf in mid-July 1988 was 


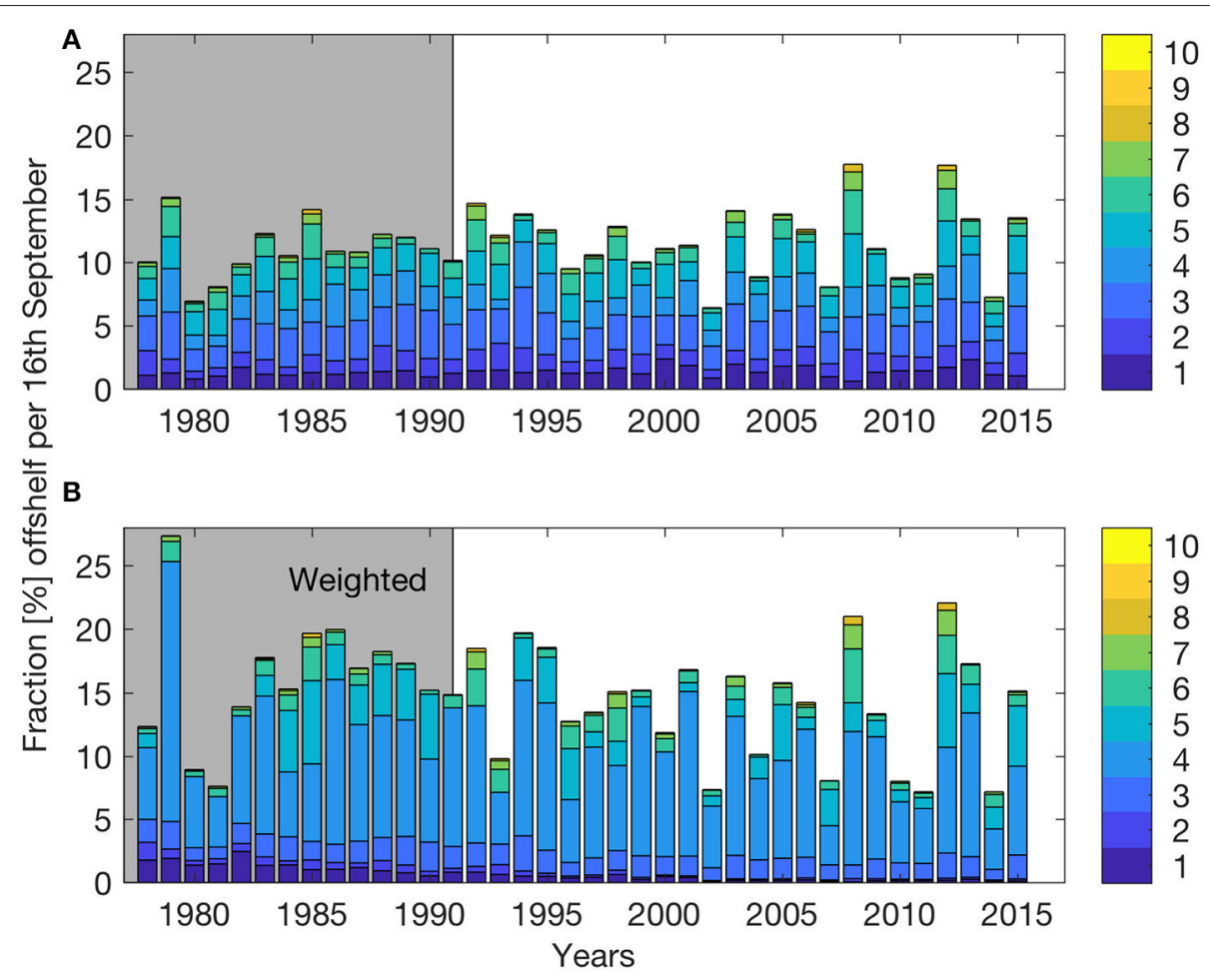

FIGURE 2 | Fraction (\%) of particles initiated at the 10 spawning grounds along the Norwegian coast that are transported off the shelf edge (>500 m) per September 16th for the years 1978-2015. Particles are released between March 1st and April 31st. (B) is identical with (A) except that particles are weighting according to observed spawning intensity in space and time. Each bar differentiates between particles originating from the different spawning grounds, see colorbar and Figure $\mathbf{1}$. Gray shading indicates years with available pelagic juvenile observations.

35\%. From our weighted simulations, the 1988 off-shelf transport was estimated to be $16.7 \%$, about half of what was calculated from field observations, but close to the simulated average in our simulations. When averaged over all years, Table 2 shows that the weighted model distributions of pelagic juveniles compare with observations in $62.4 \%$ of the observational stations, varying yearly between 40 and $79 \%$.

\section{Mechanisms Causing Off-Shelf Transport}

Here, we propose two major causes of off-shelf flows; (1) mesoscale eddies related to baroclinic instability of the alongshelf flow, and (2) a larger-scale interior Ekman transport related to wind forcing (Brink, 2016). Since we have used either a model with horizontal resolution of 4 by $4 \mathrm{~km}$, not properly resolving mesoscale variability (Isachsen et al., 2012), or a finer-resolved grid where the lateral boundary off shelf is close to the shelf edge, we focus on the effects of periodic wind forcing.

Figure 3 shows the number of particles (from non-weighted spawning grounds) displaced off the shelf edge per day for three sample years (1987-1989) between March 1st and July 31st. Here we have investigated the non-weighted model results since the focus is on understanding the physical forcing. The time series show that off-shelf transport is dominated by episodic events and that frequencies and timing varies significantly between years. In the area between 67 and $70^{\circ} \mathrm{N}$ (black line in Figure 3), 1987 has two main events (one late March and one mid-June; Figure 3A),
1988 has several events between late April to mid-June with a maximum at May 20th (Figure 3B), while in 1989 there are several small events from May to August (Figure 3C).

It seems that changing wind directions have a major impact on off-shelf transport of eggs, larvae and juveniles. Having identified off-shelf events (Figure 3), we correlated these events in the area between 67 and $70^{\circ} \mathrm{N}$ with the occurrence of two opposite wind sectors (the NE and SW sectors as described in section Predominant Wind Directions and Shelf Edge Orientation) for the period between March 1st and July 31st. Events are defined as days when the number of particles crossing the shelf edge is higher than one standard deviation of the variability for the yearspecific period (see Figure 3). Figure 4 shows the correlation between the frequency of such events and the NE and SW winds. There is a significant $(p=0.003)$ positive (negative) correlation with NE (SW) wind sector of $R^{2}=0.22(0.23)$.

A similar procedure is done correlating the frequency of winds directly against the modeled ocean currents at different depths. The correlation between NE (SW) wind sector and the current component perpendicular to the shelf edge (at the $500 \mathrm{~m}$ isobath), when the current component is above one standard deviation for the year-specific period, is $R^{2}=0.67(0.45)$ with significance for the surface current (Table 3). Corresponding correlations for currents in the depth intervals $5-10 \mathrm{~m}$ and $5-40 \mathrm{~m}$ are $R^{2}=0.48(0.28)$ and $R^{2}=0.20(0.06$, though not significant), respectively. These depths are relevant because 
TABLE 2 | Coinciding presence or absence of pelagic juveniles in modeled and observed data at the year-specific observation locations.

\begin{tabular}{|c|c|c|c|c|c|c|c|c|c|c|c|c|c|c|c|}
\hline Year [19-] & 78 & 79 & 80 & 81 & 82 & 83 & 84 & 85 & 86 & 87 & 88 & 89 & 90 & 91 & Mean \\
\hline Match [\%] & 71 & 58 & 64 & 68 & 53 & 40 & 72 & 73 & 50 & 49 & 57 & 75 & 65 & 79 & 62.4 \\
\hline
\end{tabular}

Match (\%) between the weighted model distributions and observations occur if both show presence or absence of pelagic juveniles within an area of four grid cells.

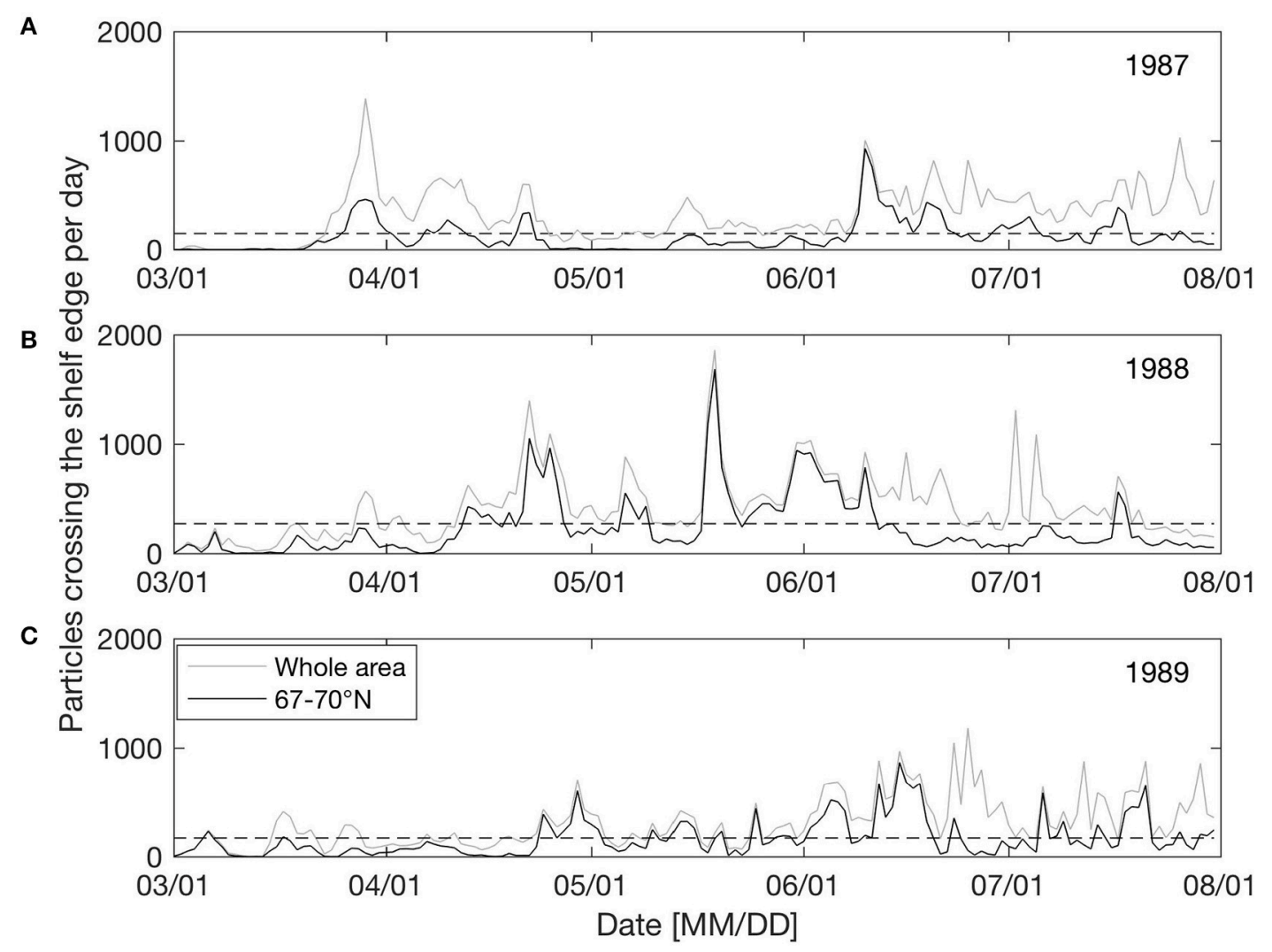

FIGURE 3 | Number of particles (from non-weighted spawning grounds) transported off shelf per day between March 1 st and July 31 st for the years 1987 (A), 1988 (B), and 1989 (C), differentiating between off-shelf transport occurring in the whole model area (gray) and between 67 and $70^{\circ} \mathrm{N}$ (black). The black dashed horizontal line indicates one standard deviation of variability.

eggs are distributed with increasing concentrations toward the surface, while larvae avoid the surface layers and occupy the depths between 5 and $40 \mathrm{~m}$ (Ellertsen et al., 1984; Kristiansen et al., 2014) depending on various cues such as prey, predators, and light. Further analysis shows that $83.0 \%$ of the daily crossshelf flow events coincides with the occurrence of $\mathrm{NE}$ wind ( $>5$ $\mathrm{m} / \mathrm{s}$ ) during the previous $24 \mathrm{~h}$. Comparing events of stronger cross-shelf currents and winds, show that NE winds above $7 \mathrm{~m} / \mathrm{s}$ coincide with 90.3 or $97.6 \%$ of the cross-shelf currents above 11 or $20 \mathrm{~cm} / \mathrm{s}$.

On average for all years, $64.6 \%$ of the off-shelf (particle) events between March 1st and July 31st have mean winds coming from NE during the three prior days before each event (Figure 5). This result is even strengthened by comparing with winds preceding such events by 5-7 days (68.2-70.6\% respectively). In particular, the years 1985, 1987, 1995, 2004, and 2014 have co-occurring mean 3 -day NE winds in $>80 \%$ of the events.

\section{Transport Pattern of Pelagic Juveniles Off the Shelf Edge}

Observations from the pelagic juvenile surveys (1978-1991) show that pelagic juveniles are variably present all years off the shelf and that the individual juveniles are larger than those on the shelf, except for the year 1979 (Table 1). Modeled dispersal of particles representing pelagic juvenile drift from the time of observations during summer to November 1st shows large interannual variations in distribution, but also characteristic features that are repeated between years (Figure 6). Pelagic juveniles drift with near-surface currents largely by the following main routes: back onto the adjacent eastern shelves and into the Barents Sea (south of Svalbard and in the Bear Island Trough), to the west and north of Svalbard with a fair chance of eventually ending up in the Barents Sea, west toward Jan Mayen, northwest toward the Greenland shelf, or recirculating within the Lofoten Basin. Separating particles by their position at November 1st into three 

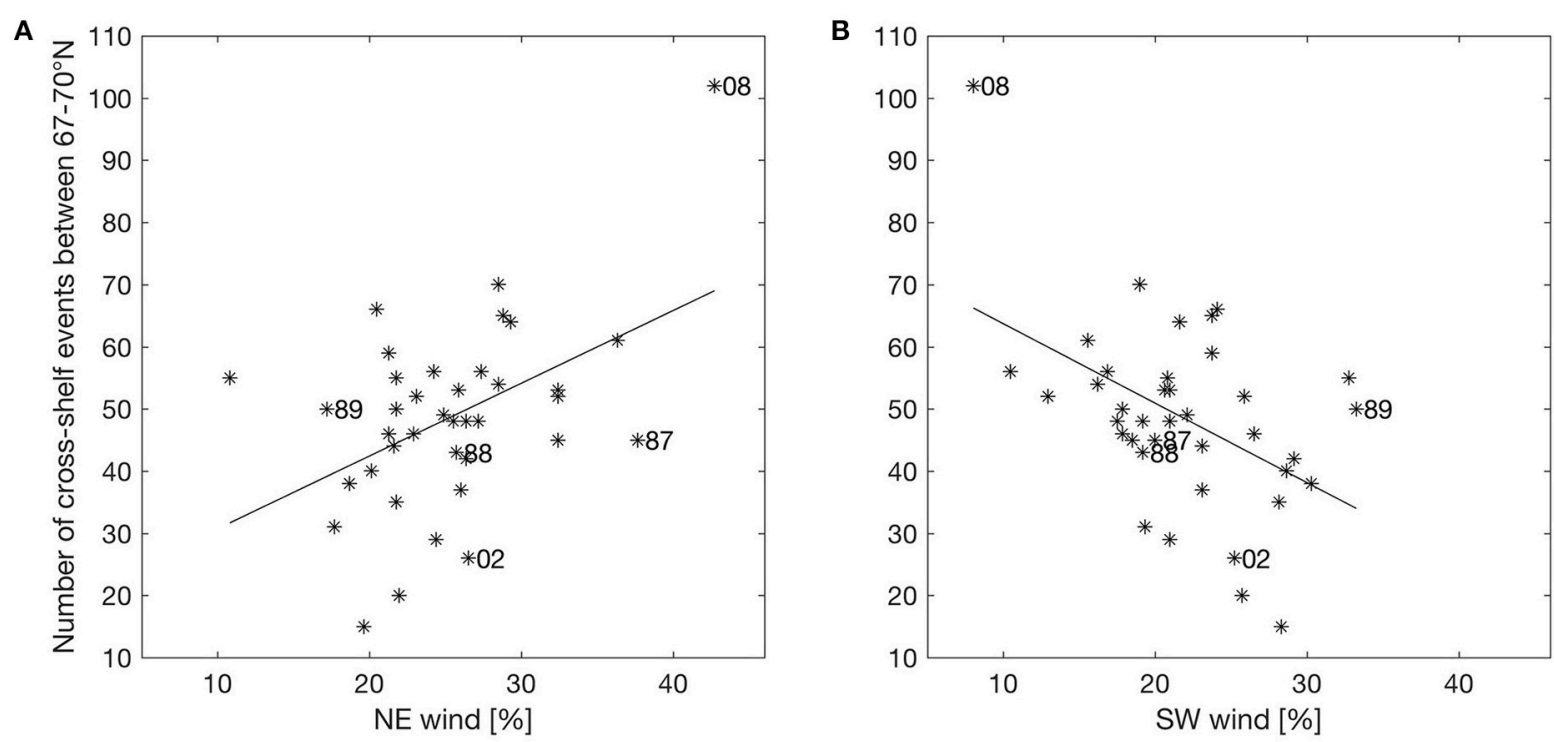

FIGURE 4 | Scatterplot of percentage wind in sectors NE (A) and SW (B) against number of events where transport of particles exceeds one standard deviation of variability from March 1st to July 31st between 67 and $70^{\circ} \mathrm{N}$ for the years 1978-2015. Years are marked with stars, where the linear regression lines are shown as solid black lines. The years discussed explicitly in the text are labeled.

TABLE 3 | The correlation $\left(R^{2}\right)$ and significance $(P)$ between wind sectors (northeastern NE or southwestern SW) and current components at three different depth intervals perpendicular to the shelf edge.

\begin{tabular}{lll}
\hline Depth & $\mathbf{R}^{\mathbf{2}} / \mathbf{P}$ (NE) & $\mathbf{R}^{\mathbf{2}} \mathbf{P}$ (SW) \\
\hline Current at top layer (3 m) & $0.67 / 0.000$ & $0.45 / 0.000$ \\
Current between 5 and 10 m & $0.48 / 0.000$ & $0.28 / 0.001$ \\
Current at 5-40 m & $0.20 / 0.005$ & $0.06 / 0.140$ \\
\hline
\end{tabular}

$(A-C)$ areas enables quantification of inter-annual variability in the destiny of the pelagic juveniles off-shelf (Figure 1);

(A) The Barents Sea with depths shallower than $500 \mathrm{~m}$.

(B) Deep ocean with depths deeper than $500 \mathrm{~m}$, (depth $>500 \mathrm{~m}$, lon $>2{ }^{\circ} \mathrm{E}$ and lat $\left.>73.5^{\circ} \mathrm{N}\right) \mid($ depth $>500 \mathrm{~m}$ and lat $<$ $\left.73.5^{\circ} \mathrm{N}\right)$.

(C) Crossing the Fram Strait to northeastern Greenland $\left(<2^{\circ} \mathrm{E}\right.$ and $\left.>73.5^{\circ} \mathrm{N}\right)$.

Table 1 shows that on average 36.9\% of the off-shelf juveniles are advected back onto the eastern shelf into the Barents Sea habitat (A), $60.7 \%$ remain in the open ocean (B), and $2.4 \%$ head toward the northeastern Greenland shelf $(\mathrm{C})$. Inter-annual variation is large, especially for area $\mathrm{C}$. The fraction of pelagic juveniles transported into $C$ varies between 0.0 and $12.1 \%$. NEA cod offspring advected off the shelf edge have a chance of being transported back onto the shelf (A) where the main nursery grounds are located (Olsen et al., 2010) without performing directional swimming, varying between 21.6 and 52.0\% (except 1980 , but this year only has a single observation of pelagic juveniles off-shelf and, hence, few particles are initiated for dispersal simulation).

\section{DISCUSSION}

A characteristic attribute of the NEA cod is that the mature part of the population migrates out of its feeding habitat in the Barents Sea to spawn along the Norwegian coast during spring. During the subsequent period from March until September, the pelagic offspring are transported northward by the NCC (and partly by the NASC) toward their feeding habitat in the Barents Sea. The present study has focused on the portion of this pelagic offspring that become advected off the shelf into the Norwegian Sea, and traditionally assumed to be lost for recruitment (defined as Hjort's 2nd hypothesis by Sinclair et al., 1985). We have investigated the origin of such juvenile loss, the driving mechanisms of this transport, and challenged Hjort's 2nd hypothesis with exploration of alternative fates of these individuals.

Our results show that off-shelf transport has strong interannual variations varying between 7.2 and $27.4 \%$ with an average of $14.7 \%$ during the years 1978-2015. Spawning grounds around Lofoten, especially the one located near the shelf edge (spawning site 5 in Figure 1) used by spawning cod in some years, contribute the most to off-shelf transport. The continental shelf is at its narrowest immediately downstream of this area (about $10 \mathrm{~km}$ wide at $69.5^{\circ} \mathrm{N}$ ), resulting in closer dynamic interactions between the NCC and the NASC branches manifested by enhanced mixing and current instabilities.

According to field observations (Suthers and Sundby, 1993), the fraction of pelagic juveniles found off shelf in mid-July 1988 was 35\%. From our weighted simulation, the 1988 offshelf transport was estimated to be $16.7 \%$, about half of the field observation, and close to the simulated average of $14.7 \%$. This indicate that our estimations of off-shelf transport might be an underestimation compared to what is 


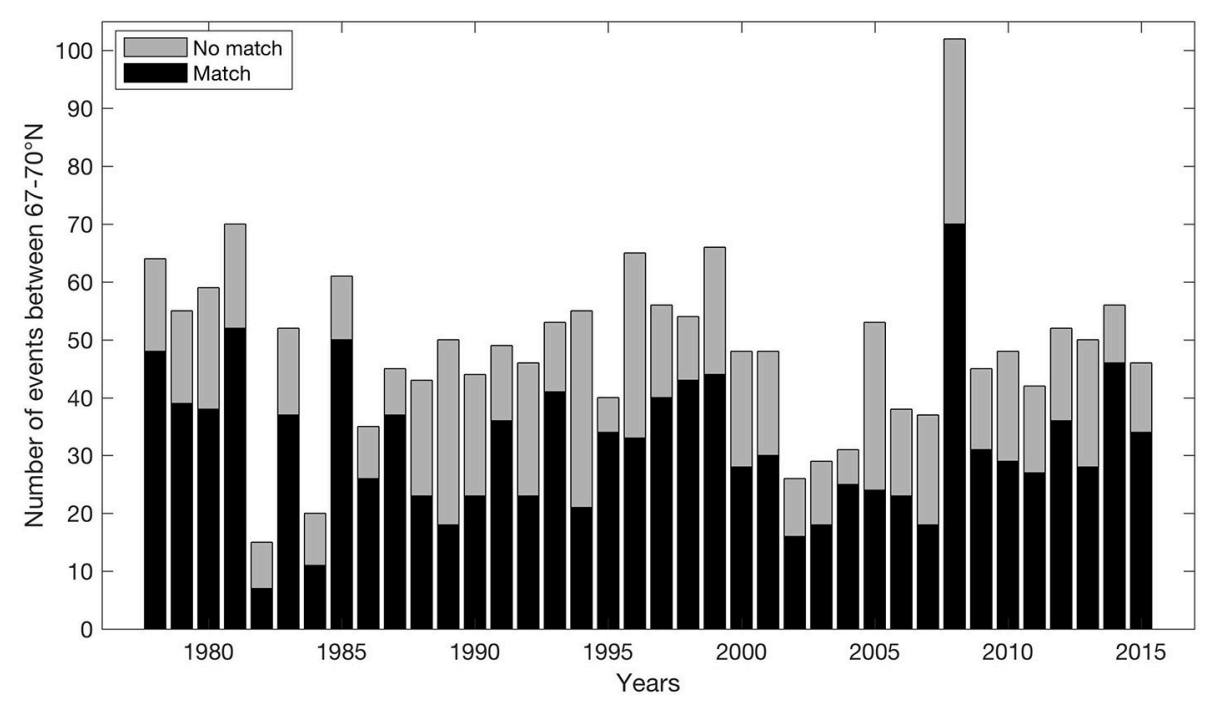

FIGURE 5 | Match between events where transport of particles off-shelf exceeds one standard deviation of variability from March 1 st to July 31 st between 67 and $70^{\circ} \mathrm{N}$ and occurrences of mean NE wind situations during the three proceeding days before each event.

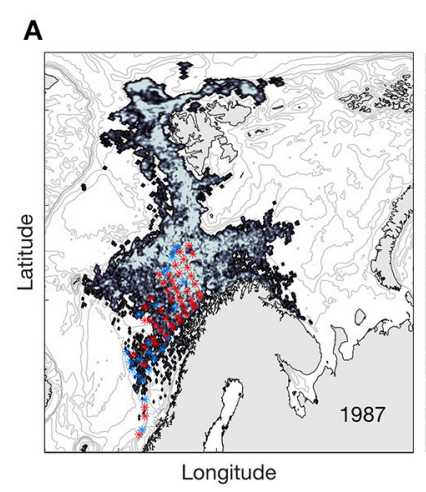

B

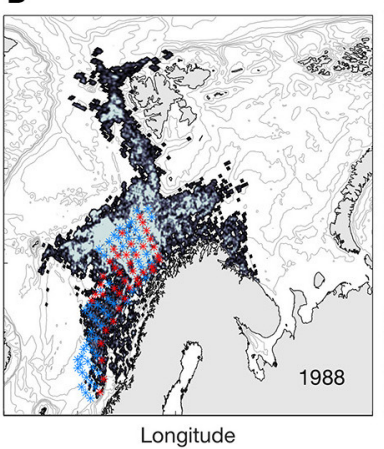

C

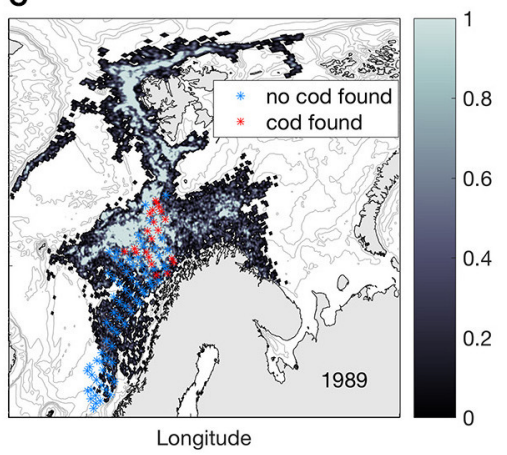

FIGURE 6 | Normalized concentrations of NEA cod pelagic juveniles per November 1st for years 1987 (A), 1988 (B), and 1989 (C) when originating from the year-specific observed pelagic juvenile distribution during summer (red stars). The years 1987-1989 have approximately an equal number of trawl stations during the pelagic juvenile cruises, here illustrated by red and blue stars indicating with and without cod in the trawl. Survey stations taken on the continental shelf is not included. Note that the modeled distributions are smoothed across 5 by 5 grid cells.

transported into the Norwegian Sea each year. It should be emphasized that not only advectional mechanisms may cause such differences between observed and modeled distributions. Offspring mortality differs substantially in time and space (e.g., Langangen et al., 2014) and will contribute to changes in spatial distributions. As demonstrated by Suthers and Sundby (1993) the main portion of the observed pelagic juveniles in 1988 originated from a spawning window 2 weeks after peak spawning implying an offspring mortality that differs substantially in time. Moreover, the fact that observed off-shelf juveniles in 1988 (Suthers and Sundby, 1993) were larger than those at the shelf they likely also had higher survival rates as they have outgrown some of their natural predators. Since mortality is not included in the biophysical model used here, this explains parts of the difference between modeled and observed off-shelf abundances.
Daily off-shelf advection of pelagic NEA cod offspring is dominated by episodic events where frequencies and timing varies between years. One important driving mechanism for these events are here shown to be fluctuating wind regimes, where northeasterly winds, especially winds blowing steadily over a period of several days (3-7 days), favor off-shelf transport. The correlation between NE winds and near-surface ocean currents weakens with depth down to $40 \mathrm{~m}$, the depth-interval relevant for cod eggs and larvae drift, showing the importance of vertical placement of NEA cod offspring for off-shelf transport.

Based on observations of pelagic juvenile NEA cod in the Norwegian Sea we simulated the potential onward drift to explore possibilities of reaching other favorable destinations than the Barents Sea habitat, i.e., other shelf areas in the North Atlantic. An average of $36.9 \%$ are advected back onto the shelves of the Barents Sea by November 1st and thereby given the opportunity 
to re-enter the NEA cod stock in its natural habitat. This includes juveniles following AW north of Svalbard. Most pelagic juveniles (average of $60.7 \%$ ) remain in the deep Norwegian Sea, thus not reaching areas where it is possible to bottom-settle due to the depths $(>2,000 \mathrm{~m})$. Hence, this portion of the offspring is confirming the destiny suggested by Hjort's second recruitment hypothesis. However, within the investigated period up to $12.1 \%$ (average of $2.4 \%$ ) heads toward the northeastern Greenland shelf, pre-conditioning bottom-settlement if the conditions are otherwise good.

\section{Connectivity Studies on Atlantic Cod}

A recent model study (Myksvoll et al., 2014) indicates that exchange of pelagic offspring between Norwegian coastal cod and NEA cod may occur to a limited extent. However, the study indicates that exchange is dominated by export of offspring from the coastal cod populations to the NEA cod population (Myksvoll et al., 2011).

Connectivity studies over a larger geographical area were undertaken by researchers on Iceland in the 1970s (e.g., Jamieson and Jónsson, 1971). They found a West Greenland component of the spawning cod at Iceland from tagging experiments implying that connections between neighboring shelves are possible. Also here, the dominating exchange was from the Icelandic cod population to the West Greenland cod population. This is a result of the general circulation patterns where the pelagic offspring are advected downstream. Export the other way must be caused by active migration of the mature fish back to their origins of birth, i.e., natal homing.

During the previous warm period (1920s and 1930s) there was an increase of Atlantic cod in western Greenland. Cod appeared at the offshore banks and expanded their habitat northwards. This is believed to be caused by increased transport of larvae from Iceland as well as better survival due to higher abundance of zooplankton (Drinkwater, 2006).

Observational and modeling studies at Georges Bank in the northwestern Atlantic Ocean (e.g., Lough et al., 1994; Lough and O'Brien, 2012) showed that wind conditions leading to off-shelf Ekman transport is detrimental for survival in early life stages of cod. The Gulf stream is located just south of Georges Bank, and cod transported off the bank will be transported out in the large North Atlantic basin and become lost for recruitment, making this a straightforward example of Hjort's 2nd hypothesis.

Our results show similarities with the Greenland-Iceland study where most juveniles advected off-shelf are lost, but where a minor fraction may get back onto a shelf-either into the well-known nursery grounds or a new location. During the previous warm period in our focus area (the 1930s), Iversen (1934) summarized observations indicating cod could spawn as far north as west of Svalbard. If this re-occurs during the current or future warm periods, there is an even shorter distance from spawning grounds to potential nursery areas at the Greenland shelf.

From the Global Drifter Program ${ }^{3}$, one drifter $(\mathrm{id}=78758$ ) from 2009 showed similar transport characteristics as here shown for young NEA cod pelagic juveniles reaching the northeastern

${ }^{3}$ http://www.aoml.noaa.gov/envids/gld/krig/parttrk_id_temporal.php
Greenland shelf (see Figure 1). This drifter consisted of a surface buoy, a transmitter, a temperature sensor and a subsurface drogue of $15 \mathrm{~m}$ depth (Koszalka et al., 2011) representing a drift in the upper ocean comparable with NEA cod offspring (vertical migration between about 5 and $30 \mathrm{~m}$ ). The drifter crossed the Norwegian continental shelf edge at February 8th 2009 , and arrived at the northeastern Greenland shelf July 27th 2009 , a journey of $\sim 6$ months. This is well within the period when cod should locate the seabed and become stationary (the Greenland shelf has approximately the same depth as the Barents Sea $\sim 300 \mathrm{~m}$ ). This observed drifter's trajectory is demonstrating the potential for drift of NEA cod pelagic juveniles to the northeastern Greenland shelf.

\section{Growth, Predation, and Survival Conditions}

In this study, we have not investigated food availability along alternative drift routes for pelagic juveniles drifting off the shelf edge from late summer and through fall. However, zooplankton studies in the Fram Strait confirm that the region is rich in arctic and arcto-boreal copepods in summer (Smith, 1988) as well as during early autumn (Svensen et al., 2011). These copepod species have been identified as the key size groups of prey for pelagic juvenile cod during the spring and summer (Sysoeva and Degtereva, 1965; Sundby, 1995). During late summer the growing juvenile cod switches to larger prey (Sundby, 1995) such as krill. These species are also abundant in the Fram Strait region (e.g., Hop et al., 2006). Consequently, there is a good reason to assume that there are suitable and sufficient prey items for pelagic juvenile cod to survive during summer and early autumn. Hence, the recent observations of immature cod at the northeastern Greenland shelf (Christiansen et al., 2016), coinciding spatially with the present modeled entering region of pelagic juveniles, support the conclusion that cod may be transported, in good condition, from spawning areas along the coast of North Norway.

We have focused on the physical processes affecting the young NEA cod offspring, only including simple biological behavior such as a diurnal vertical migration, growth dependent only on temperature and year-specific choice of spawning grounds (both in time and space). If we also had included mortality as a function of prey and predator availability, the estimate of the percentage of off-shelf transport would likely change. e.g., if individuals located on the shelf are more subject to predation, in addition to being smaller (Suthers and Sundby, 1993), this would lead to higher mortality on-shelf than off-shelf, and the off-shelf percentage would increase. As outlined in the introduction of the Discussion above it is also possible that the larger juveniles off the shelf would be in a better situation to resist and survive potential harsh conditions on their way across the Norwegian Sea. An inclusion of mortality in the model is also expected to change the match between modeled and observed juvenile distributions (Table 2) since observations are formed by the sum of transport, dispersion and site-specific mortality.

\section{Homing from Northeastern Greenland to Norway?}

What may happen to NEA cod arriving at the northeastern Greenland shelf? One possibility is that the shelf will function as a distant part of the NEA cod nursery habitat, while the 
Norwegian coast still is the preferred spawning habitat. This suggestion implies the occurrence of long-distance homing. The other possibility would be that the NEA cod settle along the eastern coast of Greenland, forming a separate sub-population. We will here focus on the first possibility, the long-distance homing strategy.

The Greenland shelf is large, with approximately the same depth as the Barents Sea $(\sim 300 \mathrm{~m})$, but much of the shelf area is covered with colder water masses resulting in slower growth and possibly also being exposed to waters of less prey productivity. Keeping in mind that high latitudes have experienced recent warming, with a subsequent northward shift in boreal species (Fossheim et al., 2015), there are reasons to believe that the northeastern Greenland shelf might get increased productivity if the warming trend continues.

Tagging experiments have already shown that NEA cod tends to return to the same spawning locations along the Norwegian coast where it was tagged, and that cod from different spawning locations occupies different areas of the Barents Sea (Godø, 1984). As mentioned in the introduction, a traditional folklore opinion in some fishing communities says that Greenland cod occasionally spawn in Norwegian waters. The hypothesis is that the Norwegian fishermen are recognizing specific phenotypic traits of the cod which are characteristic for cod growing up in Greenland waters, suggesting a long-distance homing strategy. Considering distances for such a migration pattern, the cod could either take a route directly across the Norwegian Sea $(\sim 1,000$ $\mathrm{km}$ ), or crossing the Fram Strait following the continental shelf edge (against the NASC) toward Lofoten $(\sim 1,500 \mathrm{~km})$. Both routes are within the distance range of observed migration from the Barents Sea to the spawning sites along the Norwegian coast (Sundby and Nakken, 2008; Yaragina et al., 2011). As mentioned in section Connectivity Studies on Atlantic Cod, Jamieson and Jónsson (1971) found that connectivity (homing) between neighboring shelves are possible, and already happening between southwestern Greenland to spawning grounds at Iceland. The difference between our suggested migration and the one described by Jamieson and Jónsson (1971) is that cod from Greenland to Norway need to migrate over deep waters (deeper than 2,000 m). To our knowledge, there is no literature describing deep ocean migration of NEA cod or other cod populations, making our suggested migration unique. A recent study, however, discusses observations of cod in deep waters of the Fram Strait feeding on a mesopelagic layer, demonstrating its highly adaptive capacity (Ingvaldsen et al., 2017).

\section{Model Uncertainties}

In general, the ROMS model setup applied to produce the SVIM seems to overestimate topographic steering above steep slopes. Lien et al. (2014) reported extraordinary strong horizontal gradients in hydrography along the continental shelf slope and AW with a limited westward distribution as compared to observations. This is likely the reason for less stratification on the shelf and the shelf slope as compared to observations, and in turn a different vertical impact of wind stress than in reality. We believe this also affects the ability of the model to replicate eddies shedding off the shelf (Isachsen et al., 2012).
Surprisingly, a higher horizontal grid resolution in NorKyst800, a comparable ROMS setup, did not improve the off-shelf transport, but instead reduced the percentage as compared to observations. Since NorKyst800 applies SVIM-results as forcing along its open boundaries and is thus highly affected by the density field in the coarser model, our results from both model runs are thus limited by the intense horizontal gradients in hydrography. We expect that utilizing forcing fields with improved stratification would give more accurate results. In comparison, the study by Hattermann et al. (2016) successfully quantified eddy-induced westward transport of AW across the Fram Strait and emphasized the need for high horizontal resolution in the ocean model. Their model setup was comparable to the ROMS setup in NorKyst800 but limited to the western shelf of Svalbard. In light of the results by Hattermann et al. (2016), showing that ROMS is capable of replicating eddy shedding, we expect that the relative intra- and inter-annual variation reported in our study are representative for the frequency of off-shelf transport but that the strengths are underestimated as compared to reality. Furthermore, if waves were included in the ocean circulation model, the wave-induced drift could lead to higher retention toward the coast for the cod juveniles (Röhrs et al., 2014). Also looking at ocean dynamics with time scales less than daily, tides would likely change the transport pathways in Vestfjorden implying a slightly different spread of cod eggs and larvae (Lynge et al., 2010).

If there are any errors in the setup of the biophysical model this could lead to systematic errors in the drift. For example, correlation between wind forcing and modeled ocean currents perpendicular to the shelf edge at three different depth intervals demonstrated that the vertical distribution of NEA offspring and their vertical migration affect the chance of being displaced off the shelf. The higher up in the water column, the higher chance of being transported off-shelf. We performed a sensitivity test, with particles drifting without any vertical movement but kept at fixed depths; surface, 5 and $40 \mathrm{~m}$. Results from this showed that pelagic juveniles drifting close to the surface have a more dispersed horizontal distribution, while the deeper drift pattern was more trapped along topographic features following the Norwegian coast more closely. This is in accordance with Vikebø et al. (2005, 2007) and shows the importance of accurate description of the vertical placement of NEA cod to obtain correct pelagic drift pattern. Important factors to be determined are egg buoyancy (Sundby and Kristiansen, 2015), and realistic vertical migration of the larvae and juveniles (Kristiansen et al., 2014) as well as correct vertical current profile.

The number of observation sites, and observations with and without pelagic juveniles present varied a lot between years. Hence, the number of particles initiated at spawning grounds and dispersed until the time of observations should not introduce a bias in the comparison between model and observations. In contrast, if the stations were dominated by observations with (without) pelagic juveniles, a high (low) number of modeled particles would be beneficial for match. As expected, in years with a high number of observations, there is an increasing number of observations without presence of pelagic juveniles in the trawl, as the survey also covers areas beyond the extent of distribution of cod. 
There are uncertainties associated with the origin of pelagic NEA cod juveniles, mainly due to observational limitations. In our study, we defined 10 different spawning grounds along the coast of Norway, and investigated dispersal of NEA cod offspring with and without weighted spawning grounds (Figure 2). The weighting is a continuation of Table 3.1 by Sjølingstad (2007) which divided NEA cod spawning into six spawning grounds. We refined these further into 10 spawning grounds and expanded the table until 2015 using available egg-survey observations (references described in Material and Methods). Four main considerations were done in accordance with Sundby and Nakken (2008); (1) spawning outside Møre decreases with time, (2) a northward shift in spawning locations from the early 1980s have been quantified, (3) for all years, we added highest weights to the spawning grounds around Lofoten, in accordance with well-established knowledge (Sundby and Bratland, 1987; Ottersen et al., 2014), (4) the spawning ground outside Lofoten, close to the shelf edge, only occurs occasionally (Sundby and Nakken, 2008), but increased spawning has been observed here during the recent decade, similar to the observations in the 1980s (Sundby and Bratland, 1987). The effect of weighting changed the estimated mean off-shelf amount from 11.5 to $14.7 \%$. Any inaccurate quantification of the weighting would affect this estimation.

\section{Recommendations for Future Work}

Both observations and a biophysical model indicate that a significant part of the NEA cod offspring may be advected offshelf away from the typical drift routes from the spawning grounds along the Norwegian coast toward the nursery grounds in the Barents Sea. Our modeling approach focuses mainly on the physical processes, but to investigate the fate of the offshelf drifting offspring in a more biological context, it may be necessary to explore the capability and need for horizontal swimming to re-enter the nursery areas in the Barents Sea shelf area. This may be done in a combined effort including in-situ observations and biophysical models (Staaterman and Paris, 2013).

Furthermore, it is essential to determine the prey availability for offspring that are advected off-shelf. Is it sufficient for survival during pelagic free drift for durations up to several months? This may be studied through combined in-situ observations, biophysical models and remote sensing. Egg, larval and pelagic juvenile mortality involves the enigma of the recruitment problem. The main challenge of predicting the fate of the offspring is still on larval growth and survival basically involving food abundance and the distribution of predators. Site-specific mortality will clearly contribute to the variability in distribution of offspring in addition to the physical advection.

\section{REFERENCES}

Ådlandsvik, B., and Sundby, S. (1994). "Modelling the transport of cod larvae from the Lofoten area" in ICES Marine Science Symposia, Vol. 198 (Copenhagen: International Council for the Exploration of the Sea), 379-392.
A current warming trend and subsequent northward shift in boreal species (Fossheim et al., 2015) give reasons to believe that NEA cod offspring transported off-shelf toward other shelf areas, specifically northeastern Greenland shelf, may successfully settle at the shelf. If this part of the NEA cod would be able to migrate back to its well-known habitat it will contribute to even higher recruitment to the stock if this warming trend continues. The other possibility would be that the NEA cod settle along the eastern coast of Greenland, not returning to the Norwegian coast to spawn. Observational cruises to the northeastern Greenland shelf together with tagging experiments may give better insight into this issue.

Finally, ongoing work in assimilating in-situ observations in local ocean model setups show promising features with respect to replicating vertical stratification of the upper ocean inhabited by NEA cod offspring (Sperrevik et al., 2017). We believe this may improve predictive capabilities for dispersal modeling of eggs, larvae and pelagic juveniles on their critical journey toward the favorable nursery grounds in the Barents Sea.

\section{AUTHOR CONTRIBUTIONS}

All authors listed have contributed substantially, both direct and intellectually, and approved it for publication. KS, SS, and FV was responsible for formulating the hypothesis. KS performed most of the direct contribution to the work. SS and FV was responsible for synthesizing the major part of the literature. JA set up the NorKyst800 hindcast.

\section{FUNDING}

Funding support are provided by the Research Council of Norway, through the grant RETROSPECT, project number 244262 .

\section{ACKNOWLEDGMENTS}

We thank our colleague Karen Gjertsen for all the help with Figure 1, our colleague Kjell Bakkeplass for providing us the pelagic juvenile observations, and Marta Sanchez de La lama at the University of Oslo for the help obtaining the drifter data from the Global Drifter Program. We would also like to thank the two reviewers for their constructive comments.

\section{SUPPLEMENTARY MATERIAL}

The Supplementary Material for this article can be found online at: http://journal.frontiersin.org/article/10.3389/fmars. 2017.00304/full\#supplementary-material 
Sea. Fish. Res. 5, 119-161. doi: 10.1016/0165-7836(87)90 $037-3$

Bjørke, H., and Sundby, S. (1984). "Distribution and abundance of post larval northeast Arctic cod and haddock," in Proceedings of the Soviet-Norwegian Symposium on Reproduction and Recruitment of Arctic Cod, eds O. R. Godø and S. Tilseth (Bergen: Institute of Marine Research).

Bjørke, H., and Sundby, S. (1987). "Distribution and abundance indices of postlarval and 0-group cod," in Proceedings of the Third Soviet-Norwegian Symposium on the Effect of Oceanographic Conditions on Distribution and Population Dynamics of Commercial Fish Stocks in the Barents Sea, ed H. Loeng. (Bergen: Institute of Marine Research).

Brink, K. H. (2016). Cross-shelf exchange. Ann. Rev. Mar. Sci. 8, 59-78. doi: 10.1146/annurev-marine-010814-015717

Carton, J. A., and Giese, B. S. (2008). A reanalysis of ocean climate using Simple Ocean Data Assimilation (SODA). Mon. Weather Rev. 136, 2999-3017. doi: 10.1175/2007MWR1978.1

Christiansen, J. S., Bonsdorff, E., Byrkjedal, I., Fevolden, S. E., Karamushko, O. V., Lynghammar, A., et al. (2016). Novel biodiversity baselines outpace models of fish distribution in Arctic waters. Sci. Nat. 103, 1-6. doi: 10.1007/s00114-016-1332-9

Drinkwater, K. F. (2006). The regime shift of the 1920s and 1930s in the North Atlantic. Prog. Oceanogr. 68, 134-151. doi: 10.1016/j.pocean.2006.02.011

Eldevik, T., Nilsen, J. E. Ø., Iovino, D., Olsson, K. A., Sandø, A. B., and Drange, H. (2009). Observed sources and variability of Nordic seas overflow. Nat. Geosci. 2, 406-410. doi: 10.1038/ngeo518

Ellertsen, B., Fossum, P., Solemdal, P., and Sundby, S. (1989). Relation between temperature and survival of eggs and first-feeding larvae of northeast Arctic cod (Gadus morhua L.). Rapports et Procès-Verbeaux Réunion Conseil Permanent International pour l'Exploration de la Mer, 191, 209-219.

Ellertsen, B., Fossum, P., Solemdal, P., Sundby, S., and Tilseth, S. (1984). “A case study on the distribution of cod larvae and availability of prey organisms in relation to physical processes in Lofoten," in The Propagation of Cod Gadus morhua L. Flødevigen rapportserie 1-1984 (Arendal: Havforskningsinstituttet), $453-478$.

Ellertsen, B., Fossum, P., Solemdal, P., Sundby, S., and Tilseth, S. (1987). "The effect of biological and physical factors on the survival of Arcto-Norwegian cod and the influence on recruitment variability," in Proceedings of the third Soviet-Norwegian Symposium on the Effect of Oceanographic Conditions on Distribution and Population Dynamics of Commercial Fish Stocks in the Barents Sea, ed H. Loeng (Bergen: Institute of Marine Research).

Eriksen, E., and Prozorkevich, D. (2011). "0-group survey," in The Barents Sea Ecosystem, Resources, Management. Half a Century of Russian-Norwegian Cooperation, eds T. Jakobsen and V. K. Ozhigin (Trondheim: Tapir Academic Press), 557-569.

Folkvord, A. (2005). Comparison of size-at-age of larval Atlantic cod (Gadus morhua) from different populations based on size-and temperature-dependent growth models. Can. J. Fish. Aqu. Sci. 62, 1037-1052. doi: 10.1139/f05-008

Fossheim, M., Primicerio, R., Johannesen, E., Ingvaldsen, R. B., Aschan, M. M., and Dolgov, A. V. (2015). Recent warming leads to a rapid borealization of fish communities in the Arctic. Nat. Clim. Chang. 5, 673-677. doi: $10.1038 /$ nclimate 2647

Godø, O. R. (1984). "Migration, mingling and homing of north-east Arctic cod from two separated spawning grounds," in Proceedings of the Soviet-Norwegian Symposium on Reproduction and Recruitment of Arctic Cod, eds O. R. Godø and S. Tilseth (Bergen: Institute of Marine Research).

Hansen, B., and Østerhus, S. (2007). Faroe bank channel overflow 1995-2005. Prog. Oceanogr. 75, 817-856. doi: 10.1016/j.pocean.2007.09.004

Hattermann, T., Isachsen, P. E., Appen, W. J., Albretsen, J., and Sundfjord, A. (2016). Eddy-driven recirculation of Atlantic water in fram strait. Geophys. Res. Lett. 43, 3406-3414. doi: 10.1002/2016GL068323

Hjort, J. (1914). Fluctuations in the great fisheries of northern Europe viewed in the light of biological research. Rapports et Procès-Verbeaux Réunion Conseil Permanent International Pour l'Exploration de la Mer, 20, $1-228$.

Hop, H., Falk-Petersen, S., Svendsen, H., Kwasniewski, S., Pavlov, V., Pavlova, O., et al. (2006). Physical and biological characteristics of the pelagic system across Fram Strait to Kongsfjorden. Prog. Oceanogr. 71, 182-231. doi: $10.1016 /$ j.pocean.2006.09.007
Ingvaldsen, R. B., Gjøsæter, H., Ona, E., and Michalsen, K. (2017). Atlantic cod (Gadus morhua) feeding over deep water in the high Arctic. Polar Biol. doi: 10.1007/s00300-017-2115-2

Isachsen, P. E., and Nøst, O. A. (2012). The air-sea transformation and residual overturning circulation within the Nordic Seas. J. Mar. Res. 70, 31-68. doi: 10.1357/002224012800502372

Isachsen, P. E., Koszalka, I., and LaCasce, J. H. (2012). Observed and modeled surface eddy heat fluxes in the eastern Nordic Seas. J. Geophys. Res. 117:C8. doi: 10.1029/2012JC007935

Iversen, T. (1934). Some observations on cod in Northern Waters. Preliminary Report, Fiskeridirektoratets Skrifter, Serie Havundersøkelser. (Report on Norwegian Fisheries and Marine Investigations, Vol. 5.

Jamieson, A., and Jónsson, J. (1971). The Greenland component of spawning cod at Iceland. J. du Conseil Int. Pour l'Explor. de la Mer 161, 65-72.

Koszalka, I., LaCasce, J. H., Andersson, M., Orvik, K. A., and Mauritzen, C. (2011). Surface circulation in the Nordic Seas from clustered drifters. Deep Sea Res. 58, 468-485. doi: 10.1016/j.dsr.2011.01.007

Kristiansen, T., Vollset, K. W., Sundby, S., and Vikebø, F. (2014). Turbulence enhances feeding of larval cod at low prey densities. ICES J. Mar. Sci. 71, 2515-2529. doi: 10.1093/icesjms/fsu051

Langangen, Ø., Stige, L. C., Yaragina, N. A., Vikebø, F. B., Bogstad, B., and Gusdal, Y. (2014). Egg mortality of northeast Arctic cod (Gadus morhua) and haddock (Melanogrammus aeglefinus). ICES J. Mar. Sci. 71, 1129-1136. doi: 10.1093/icesjms/fst007

Lien, V. S., Gusdal, Y., and Vikebø, F. B. (2014). Along-shelf hydrographic anomalies in the Nordic Seas (1960-2011): locally generated or advective signals? Ocean Dyn. 64, 1047-1059. doi: 10.1007/s10236-014-0736-3

Lien, V. S., Hjøllo, S. S., Skogen, M. D., Svendsen, E., Wehde, H., Bertino, L., et al. (2016). An assessment of the added value from data assimilation on modelled Nordic Seas hydrography and ocean transports. Ocean Model. 99, 43-59. doi: 10.1016/j.ocemod.2015.12.010

Lough, R. G., and O’Brien, L. (2012). Life-stage recruitment models for Atlantic cod (Gadus morhua) and haddock (Melanogrammus aeglefinus) on Georges Bank. Fish. Bull. 110, 123-140.

Lough, R. G., Smith, W. G., Werner, F. E., Loder, J. W., Page, F. H., Hannah, C. G., et al. (1994). "Influence of wind-driven advection on interannual variability in cod egg and larval distributions on Georges Bank: 1982 vs 1985" in ICES Marine Science Symposia, Vol. 198 (Copenhagen: International Council for the Exploration of the Sea), 356-378.

Lynge, B. K., Berntsen, J., and Gjevik, B. (2010). Numerical studies of dispersion due to tidal flow through Moskstraumen, northern Norway. Ocean Dyn. 60, 907-920. doi: 10.1007/s10236-010-0309-Z

Myksvoll, M. S., Jung, K. M., Albretsen, J., and Sundby, S. (2014). Modelling dispersal of eggs and quantifying connectivity among Norwegian coastal cod subpopulations. ICES J. Mar. Sci. 71, 957-969. doi: 10.1093/icesjms/fst022

Myksvoll, M. S., Sundby, S., Ådlandsvik, B., and Vikebø, F. B. (2011). Retention of coastal cod eggs in a fjord caused by interactions between egg buoyancy and circulation pattern. Mar. Coast. Fish. 3, 279-294. doi: 10.1080/19425120.2011.595258

Olsen, E., Aanes, S., Mehl, S., Holst, J. C., Aglen, A., and Gjøsæter, H. (2010). Cod, haddock, saithe, herring, and capelin in the Barents Sea and adjacent waters: a review of the biological value of the area. ICES J. Mar. Sci. 67, 87-101. doi: 10.1093/icesjms/fsp229

Opdal, A. F., Vikebø, F., and Fiksen, Ø. (2011). Parental migration, climate and thermal exposure of larvae: spawning in southern regions gives Northeast Arctic cod a warm start. Mar. Ecol. Prog. Ser. 439, 255-262. doi: 10.3354/meps09335

Ottersen, G., Bogstad, B., Yaragina, N. A., Stige, L. C., Vikebø, F. B., and Dalpadado, P. (2014). A review of early life history dynamics of Barents Sea cod (Gadus morhua). ICES J. Mar. Sci. 71, 2064-2087. doi: 10.1093/icesjms/ fsu037

Reistad, M., Breivik, Ø., Haakenstad, H., Aarnes, O. J., Furevik, B. R., and Bidlot, J. R. (2011). A high-resolution hindcast of wind and waves for the North Sea, the Norwegian Sea, and the Barents Sea. J. Geophys. Res. 116, C5. doi: 10.1029/2010JC006402

Röhrs, J., Christensen, K. H., Vikebø, F., Sundby, S., Saetra, Ø., and Broström, G. (2014). Wave-induced transport and vertical mixing of pelagic eggs and larvae. Limnol. Oceanogr. 59, 1213-1227. doi: 10.4319/lo.2014.59.4.1213 
Rossby, T., Ozhigin, V., Ivshin, V., and Bacon, S. (2009). An isopycnal view of the Nordic Seas hydrography with focus on properties of the Lofoten Basin. Deep Sea Res. 56, 1955-1971. doi: 10.1016/j.dsr.2009.07.005

Shchepetkin, A. F., and McWilliams, J. C. (2005). The regional oceanic modeling system (ROMS): a split-explicit, free-surface, topography-following-coordinate oceanic model. Ocean Model. 9, 347-404. doi: 10.1016/j.ocemod.2004.08.002

Sinclair, M., Tremblay, M. J., and Bernal, P. (1985). El Ni-o events and variability in a Pacific mackerel (Scomber japonicus) survival index: support for Hjort's second hypothesis. Can. J. Fish. Aqu. Sci. 42, 602-608. doi: 10.1139/f85-078

Sjølingstad, B. B. (2007). Reconstruction of UV Radiation: UV Exposure of the Arcto-Norwegian Cod Egg Population, 1957-2005. Thesis, Bergen, Geophysical institute, University of Bergen, 1-77.

Smith, S. L. (1988). Copepods in Fram Strait in summer: distribution, feeding and metabolism. J. Mar. Res. 46, 145-181. doi: 10.1357/002224088785113720

Søiland, H., Chafik, L., and Rossby, T. (2016). On the long-term stability of the Lofoten Basin Eddy. J. Geophys. Res. 121, 4438-4449. doi: 10.1002/2016JC011726

Sperrevik, A. K., Röhrs, J., and Christensen, K. H. (2017). Impact of data assimilation on Eulerian versus Lagrangian estimates of upper ocean transport. J. Geophys. Res. 122, 5445-5457. doi: 10.1002/2016JC012640

Staaterman, E., and Paris, C. B. (2013). Modelling larval fish navigation: the way forward. ICES J. Mar. Sci. 71, 918-924. doi: 10.1093/icesjms/fst103

Sundby, S. (1983). A one-dimensional model for the vertical distribution of pelagic fish eggs in the mixed layer. Deep Sea Res. 30, 645-661. doi: 10.1016/0198-0149(83)90042-0

Sundby, S. (1995). Wind climate and foraging of larval and juvenile ArctoNorwegian cod. Can. Spec. Pub. Fish. Aqu. Sci. 121, 405-415.

Sundby, S. (2000). Recruitment of Atlantic cod stocks in relation to temperature and advection of copepod populations. Sarsia 85, 277-298. doi: 10.1080/00364827.2000.10414580

Sundby, S., and Bratland, P. (1987). Kartlegging av gytefeltene for norsk-arktisk torsk i Nord-Norge og beregning av eggproduksjonen i årene 1983-1985. (Spatial distribution and production of eggs from Northeast-arctic cod at the coast of Northern Norway 1983-1985). Fisken og Havet 1, 1-58.

Sundby, S., and Kristiansen, T. (2015). The principles of buoyancy in marine fish eggs and their vertical distributions across the world oceans. PLoS ONE 10:8821. doi: 10.1371/journal.pone.0138821

Sundby, S., and Nakken, O. (2008). Spatial shifts in spawning habitats of ArctoNorwegian cod related to multidecadal climate oscillations and climate change. ICES J. Mar. Sci. 65, 953-962. doi: 10.1093/icesjms/fsn085

Sundby, S., Bjørke, H., Soldal, A. V., and Olsen, S. (1989). Mortality rates during the early life stages and year class strength of the Arcto-Norwegian cod (Gadus morhua L.). Rapports et procès-verbaux des Réunions. Conseil permanent international pour l'Exploration de la Mer, 191, 351-358.

Suthers, I. M., and Sundby, S. (1993). Dispersal and growth of pelagic juvenile Arcto-Norwegian cod (Gadus morhua), inferred from otolith microstructure and water temperature. ICES J. Mar. Sci. 50, 261-270. doi: 10.1006/jmsc.1993.1028

Suthers, I. M., and Sundby, S. (1996). Role of the midnight sun: comparative growth of pelagic juvenile cod (Gadus morhua) from the ArctoNorwegian and a Nova Scotian stock. ICES J. Mar. Sci. 53, 827-836. doi: 10.1006/jmsc.1996.0104
Svensen, C., Seuthe, L., Vasilyeva, Y., Pasternak, A., and Hansen, E. (2011). Zooplankton distribution across Fram Strait in autumn: are small copepods and protozooplankton important? Prog. Oceanogr. 91, 534-544. doi: 10.1016/j.pocean.2011.08.001

Sysoeva, T. K., and Degtereva, A. A. (1965). The relation between feeding of cod larvae and pelagic fry and the distribution and abundance of their principal food organisms. Int. Comm. Northwest Altan. Fish. Spec. Pub. 6, 411-416.

Thygesen, U. H., and Ådlandsvik, B. (2007). Simulating vertical turbulent dispersal with finite volumes and binned random walks. Mar. Ecol. Prog. Ser. 347, 145-153. doi: 10.3354/meps06975

Umlauf, L., and Burchard, H. (2003). A generic length-scale equation for geophysical turbulence models. J. Mar. Res. 61, 235-265. doi: 10.1357/002224003322005087

Umlauf, L., Burchard, H., and Hutter, K. (2003). Extending the k- $\omega$ turbulence model towards oceanic applications. Ocean Model. 5, 195-218. doi: 10.1016/S1463-5003(02)00039-2

Uppala, S. M., Kållberg, P. W., Simmons, A. J., Andrae, U., Bechtold, V. D., Fiorino, M., et al. (2005). The ERA-40 re-analysis. Q. J. R. Meteorol. Soc. 131, 2961-3012. doi: 10.1256/qj.04.176

Vikebø, F., Jørgensen, C., Kristiansen, T., and Fiksen, Ø. (2007). Drift, growth, and survival of larval Northeast Arctic cod with simple rules of behaviour. Mar. Ecol. Prog. Ser. 347, 207-219. doi: 10.3354/meps06979

Vikebø, F., Sundby, S., Ådlandsvik, B., and Fiksen, Ø. (2005). The combined effect of transport and temperature on distribution and growth of larvae and pelagic juveniles of Arcto-Norwegian cod. ICES J. Mar. Sci. 62, 1375-1386. doi: 10.1016/j.icesjms.2005.05.017

Warner, J. C., Sherwood, C. R., Arango, H. G., and Signell, R. P. (2005). Performance of four turbulence closure models implemented using a generic length scale method. Ocean Model. 8, 81-113. doi: 10.1016/j.ocemod.2003.12.003

Werner, F. E., Page, F. H., Lynch, D. R., Loder, J. W., Lough, R. G., Perry, R., et al. (1993). Influences of mean advection and simple behavior on the distribution of cod and haddock early life stages on Georges Bank. Fish. Oceanogr. 2, 43-64. doi: 10.1111/j.1365-2419.1993.tb00120.x

Werner, F. E., Quinlan, J. A., Blanton, B. O., and Luettich, R. A. (1997). The role of hydrodynamics in explaining variability in fish populations. J. Sea Res. 37, 195-212. doi: 10.1016/S1385-1101(97)00024-5

Yaragina, N. A., Aglen, A., and Sokolov, K. M. (2011). Cod. "The Barents Sea ecosystem, resources, management," in Half a Century of Russian-Norwegian Cooperation, eds T. Jakobsen and V. K. Ozhigin (Trondheim: Tapir Academic Press), 225-270.

Conflict of Interest Statement: The authors declare that the research was conducted in the absence of any commercial or financial relationships that could be construed as a potential conflict of interest.

Copyright (c) 2017 Strand, Sundby, Albretsen and Vikebø. This is an open-access article distributed under the terms of the Creative Commons Attribution License (CC $B Y)$. The use, distribution or reproduction in other forums is permitted, provided the original author(s) or licensor are credited and that the original publication in this journal is cited, in accordance with accepted academic practice. No use, distribution or reproduction is permitted which does not comply with these terms. 